\title{
Пространственные закономерности накопления стронция в рыбах оз. Имандра (Мурманская область)
}

\author{
Терентьев П.М., Зубова Е.М., Кашулин Н.А., Королева И.М. \\ Институт проблем промышленной экологии Севера ФИЦ КНЦ РАH, Anamumbl, p.terentjev@ksc.ru
}

\begin{abstract}
Аннотация. Рассмотрены пространственные закономерности накопления стронция в тканях рыб крупнейшего арктического водоема - озера Имандра. Стронций является специфическим маркером воздействия предприятия апатито-нефелинового производства. Установлено, что загрязнение водоема стронцием в настоящее время продолжает нарастать. Анализ долговременной динамики накопления стронция в тканях сига выявил тенденцию к росту его содержания в костной ткани на протяжении тридцатилетнего периода. Бентосный тип питания, обусловливает наиболее интенсивную нагрузку $\mathrm{Sr}$ на организм сига по сравнению с хищными видами. В качестве оценочного критерия неблагополучия водоема в отношении уровской болезни рассматривается показатель соотношения $\mathrm{Ca} / \mathrm{Sr}$ в исследованных тканях сига. Показано, что величины указанного индекса, несмотря на отсутствие значимых предпосылок к возникновению нарушений развития костной ткани у рыб, имеют выраженную градиентную закономерность от нагрузки стронция на водоем.
\end{abstract}

Ключевые слова: стронций, загрязнение вод, рыбы, Арктический водоем

\section{Spatial particularities of Sr accumulation in fish of Lake Imandra (Murmansk region)}

\author{
Terentjev P.M., Zubova E.M., Kashulin N.A., Koroleva I.M. \\ Institute of North Industrial Ecology Problems KSC RAS, Apatity, p.terentjev@ksc.ru
}

\begin{abstract}
The spatial particularities of $\mathrm{Sr}$ accumulation in fish tissues of the largest Arctic reservoir (Lake Imandra) were investigated. Sr is known to be is a specific marker of an apatite-nepheline industry influence. It has been established that $\mathrm{Sr}$ pollution of the lake has the tendency to increase at present. The analysis of the thirty-year period of $\mathrm{Sr}$ accumulation in whitefish tissues revealed a tendency to increase its content in bone tissues. Being a benthivorous whitefish is the most vulnerable to intense $\mathrm{Sr}$ accumulation in organs compared to predatory species. An indicator of the $\mathrm{Ca} / \mathrm{Sr}$ ratio in the whitefish tissues was proposed as evaluation criterion for the lake pollution in relation to a "urovskaya disease". It was shown that the values of this index, despite the absence of significant prerequisites for the occurrence of bone tissue disturbances of fish, have a straight gradient pattern according to the Sr load value on waters.
\end{abstract}

Key words: Strontium, water pollution, fishes, Arctic water body.

\section{Введение}

К числу широкого круга загрязняющих веществ связанных, главным образом, с деятельностью горнодобывающей промышленности и поступающих в экосистему оз. Имандра, относится стронций. Среди металлов в фосфатном сырье и производимых минеральных удобрениях на его долю приходится значительное количество (Петренко, Белюченко, 2014). Стронций содержится в составе компонентов тонкодисперсных взвесей сточных вод Кировского филиала АО «Апатит», при фильтрации технологических стоков через дамбу хвостохранилища, а также за счет процессов аэротехногенного переноса с хвостохранилищ (Моисеенко и др., 2002). Содержание Sr в апатитовой руде, концентрате и хвостах АНОФ-ІІ АО «Апатит» составляет 1.39, 3.13 и 0.37 \% соответственно (Moiseenko et al., 1996).

В исследованиях, касающихся изучения токсического влияния стронция на растения и животных, традиционно уделяется внимание либо в контексте воздействия его радиоактивных изотопов (Василенко, Василенко, 2002), либо в ходе анализа закономерностей накопления этого элемента в районах с аномально высоким его содержанием в природных водах, почвах и развитием специфических заболеваний (Полякова, 2012). Стронций содержится во всех растительных и животных организмах. Физиологическое значение стабильного стронция остается недостаточно изученным. Счи- 
тают, что он участвует в обменных процессах в костной ткани, повышает фосфатазную активность эпифизарного хряща и образующейся костной ткани (Моисеенко и др., 2002). В то же время, избыточное содержание его в организме сопряжено с опасностью развития уровской болезни (болезни Кашина-Бека), которая проявляется в заболевании суставов, повышенной ломкости и уродством костей (Василенко, Василенко, 2002).

Несмотря на относительно низкие содержания стронция в водах оз. Имандра (в среднем около 0.06 мг/л) при существующих ПДК на уровне 7 мг/л (ГН 2.1.5.1315-03.), загрязнение озера стронцием продолжает нарастать. Кроме того, стронций в значительных количествах накапливается в донных отложениях и тканях рыб, особенно в жабрах и скелете. В связи с этим целью настоящей работы является оценка пространственно временных особенностей накопления стронция в организмах рыб оз. Имандра.

\section{материалы и методы}

Материалом работы послужили результаты исследований ИППЭС КНЦ РАН, начиная с конца 1980-х гг., продолжающихся до настоящего времени. Работы по оценке состояния рыбной части сообществ озера Имандра проводились в акватории трех плесов озера. Для определения содержания металлов в органах и тканях, отбиралось 10-15 экземпляров рыб одинакового размера. Отбирались пробы печени, почек, жабр, кусочки ткани и скелета (позвоночник). В лабораторных условиях пробы органов высушивали до постоянного веса в сушильном шкафу при температуре $90^{\circ} \mathrm{C}$, после чего органическую матрицу удаляли в растворе концентрированной азотной кислоты в микроволновой системе разложения (Multivave 3000, Anton Paar, Austria) с дальнейшей фильтрацией. Определение содержания металлов проводилось методом атомно-адсорбционной спектроскопии.

\section{Результаты и обсуждение}

Исходя из данных гидрохимического опробования, наиболее высокие концентрации стронция наблюдаются в зонах, которые непосредственно прилегают к губе Белой, в которую поступают стоки Кировского филиала АО «Апатит». Было показано, что, несмотря на спад производства, снижения содержания стронция в воде озера за последнее десятилетие не происходит. Основной вклад в загрязнение озера этим элементом, очевидно, вносит ветровая эрозия хвостохранилищ (Моисеенко и др., 2002).
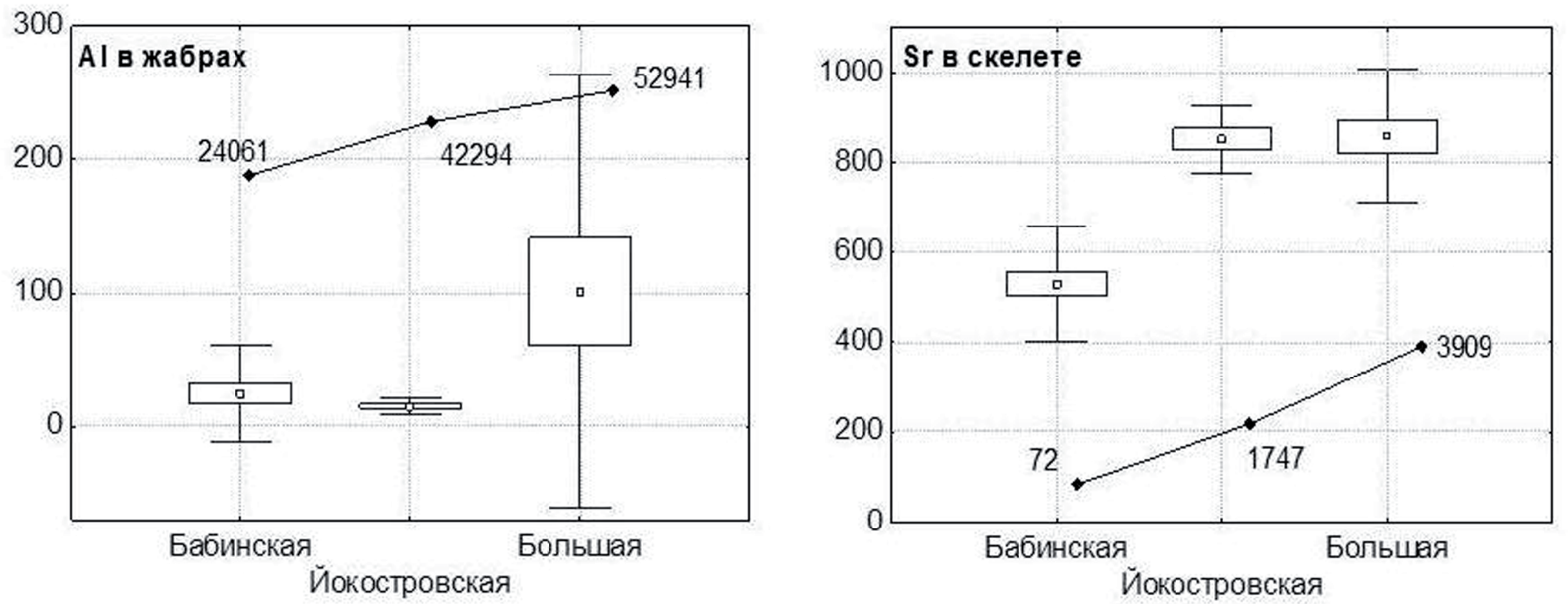

Рис. 1. Уровни накопления алюминия и стронция в органах сига (диаграмма размаха) и донных отложениях (кривая) различных плесов оз. Имандра (в мкг/г сухого веса).

Fig. 1. Accumulation levels of $\mathrm{Al}$ and $\mathrm{Sr}$ in whitefish organs (span chart) and in bottom sediments (curve) of the different stretches of the Lake Imandra (in $\mu \mathrm{g} / \mathrm{g}$ dry weight). 
В целом, нагрузка тяжелых металлов (ТМ) на экосистему оз. Имандра в настоящее время остается на значительном уровне. Для стронция характерны значительные абсолютные показатели накопления в организмах рыб, в особенности в костной ткани. Отмечено, что концентрации стронция в анализируемых органах снижались в следующем порядке: скелет>жабры>печень>почки>мы шцы. Его содержание в исследованных органах в целом характеризовалось более высокими показателями в скелете рыб Йокостровской и южной и северной частях Большой Имандры. Максимальные содержания стронция в жабрах сига достигали 1153, а в скелете - 3271 мкг/г сухого веса. В поверхностных слоях донных отложений эти показатели были выше (рис. 1). Основной тенденцией при рассмотрении многолетней динамики накопления стронция в организмах сига является увеличение его содержания у рыб в настоящее время по сравнению с материалами предыдущих исследований (рис. 2). Данный элемент можно рассматривать как специфический маркер воздействия предприятия апатито-нефелинового производства. Нагрузка алюминия и стронция, влияние которых в данной части акватории водоема связано с деятельностью предприятия «Апатит» на организмы рыб, хорошо согласуется и с уровнем загрязнения этими элементами донных отложений (рис. 1).

Считается, что накопление ТМ в организмах рыб увеличивается при переходе от одного трофического уровня к другому (Мур, Раммамурти, 1987). Анализ накопления стронция в костной тка-

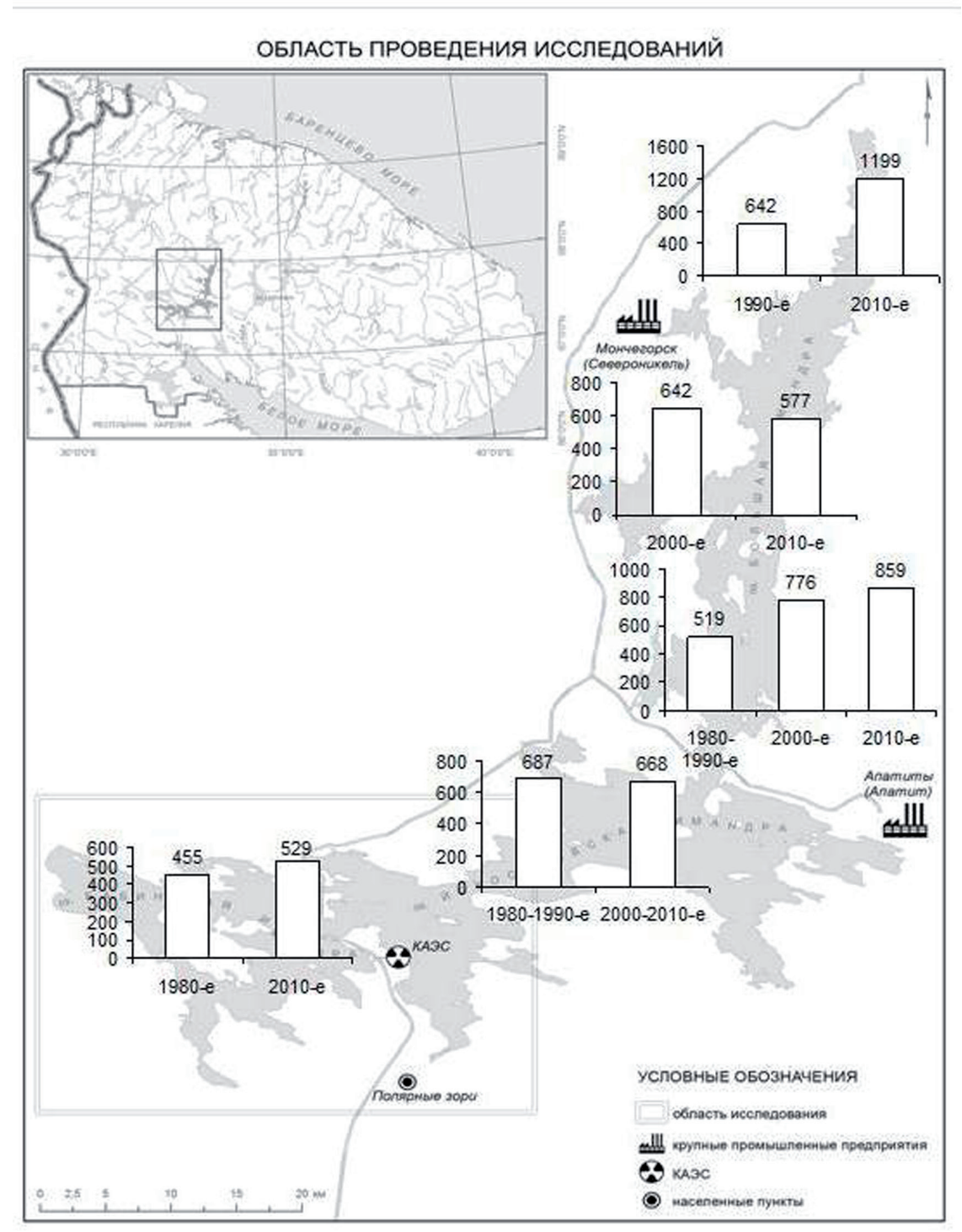

Рис. 2. Среднее содержание стронция в скелете сига оз. Имандра за различные периоды исследований. Fig. 2. Average concentration of Sr in skeleton of whitefish in Lake Imandra in different periods of the study. 


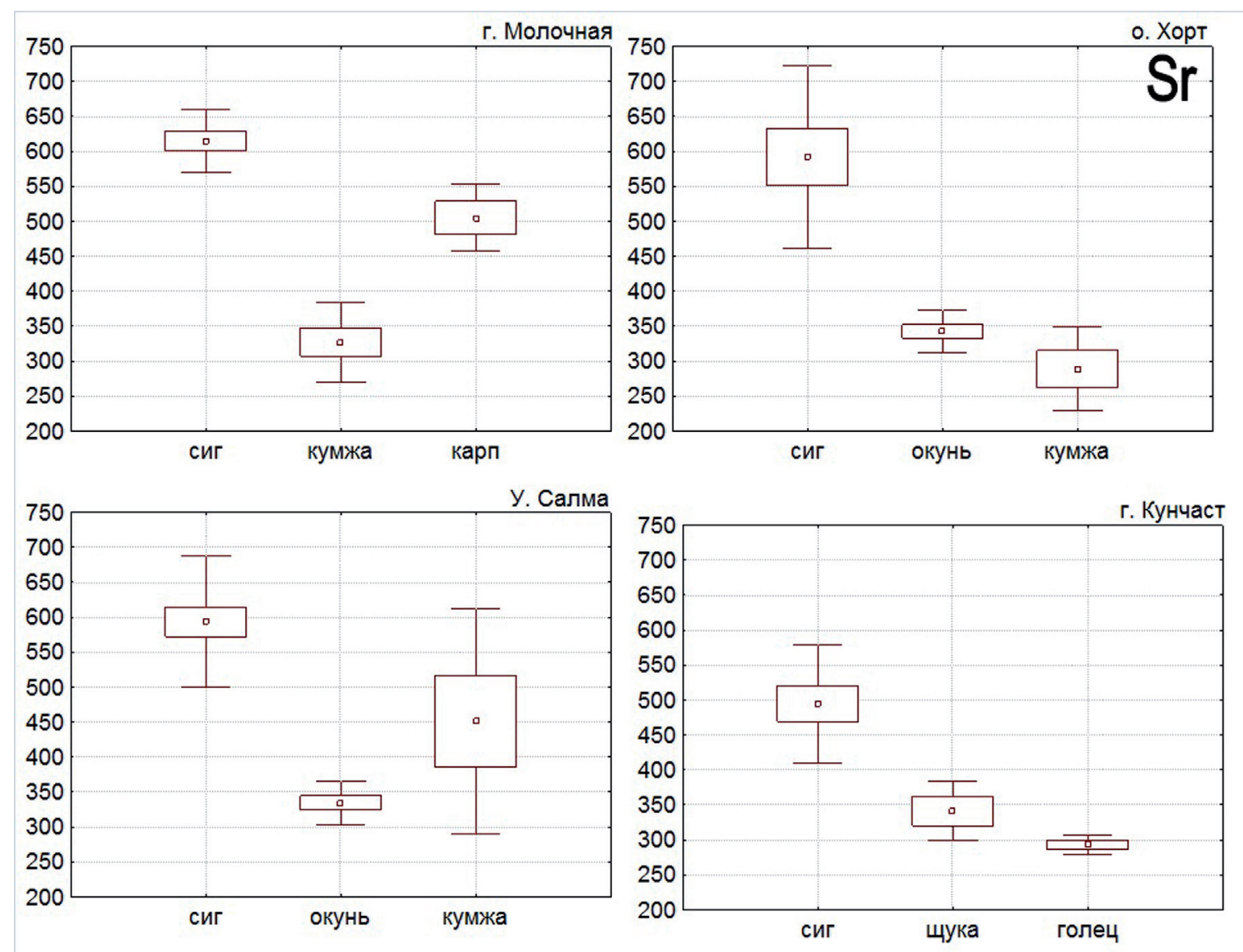

Рис. 3. Содержание стронция (скелет) у рыб Бабинской Имандры (в мкг/г сухого веса).

Fig. 3. Sr concentration (skeleton) in fishes of Babinskaya Imandra (in $\mu \mathrm{g} / \mathrm{g}$ dry weight).

ни исследованных видов рыб одного из плесов (Бабинской Имандры) показал, что для стронция, по-видимому, определяющую роль в накоплении в организме играют пищевые объекты придонных горизонтов и донных отложений (бентос), в связи с чем, наиболее высокие их содержания характерны для сига-бентофага и рыб со смешанным типом питания (рис. 3). Известно, что в бентосных организмах в условиях накопления ТМ в донных отложениях озер, загрязняющие вещества накапливаются более интенсивно.

Поскольку стронций является сопутствующим кальцию элементом и активно может заменять его в костной ткани, низкие содержания кальция в природных водах Арктики, также могут являться причиной его активного аккумулирования в организмах гидробионтов. Принято считать, что соотношение $\mathrm{Ca} / \mathrm{Sr}$ в природных водах ниже величины 100 является признаком неблагополучия территории в отношении уровской болезни (Замана, Гладкая, 1993). Согласно данным гидрохимического анализа указанный показатель для акватории оз. Имандра в среднем составляет 64.2. Показатель отношения $\mathrm{Ca} / \mathrm{Sr}$ также широко используется для оценки гигиенического качества растениеводческой продукции. В работах В.В. Ковальского (1978) указывается ориентировочное пороговое значение отношения $\mathrm{Ca} / \mathrm{Sr}$, равное 140 в пищевом рационе. При снижении этого отношения ниже 80, продукция растениеводства становится гигиенически неполноценной (Ковальский, 1978; Лаврищев, 2016). В этой связи, интерес представляет использование аналогичного индекса применительно к гидробионтам, в частности к рыбам. Негативное влияние избыточного накопления стронция в скелете животных (замены кальция на стронций) вызваны различным радиусом ядра этих элементов, что в конечном итоге может приводить к деформированию костной ткани. Однако при каком соотношении Са к Sr в скелете животных и человека возникают первые признаки заболевания не установлено (Лаврищев, 2016). Для сига, как наиболее распространенного вида в пределах акватории водоема соотношение $\mathrm{Ca} / \mathrm{Sr}$ имеет выраженную градиентную зависимость, т.е. увеличивает- 
ся по мере удаления от зон озера с более высоким уровнем нагрузки по стронцию (табл. 1). Следует отметить, что величины рассматриваемого индекса в среднем варьируют в диапазоне 112-190, что может говорить об отсутствии значимых предпосылок к возникновению нарушений развития костной ткани сига оз. Имандра на современном этапе.

Таблица 1. Величины соотношения $\mathrm{Ca} / \mathrm{Sr}$ в исследованных органах сига оз. Имандра.

Table 1. Values of $\mathrm{Ca} / \mathrm{Sr}$ ratio in whitefish tissues of Lake Imandra.

\begin{tabular}{|l|c|c|c|c|c|}
\hline \multirow{2}{*}{\multicolumn{1}{|c|}{ Район }} & \multicolumn{5}{|c|}{ Органы } \\
\cline { 1 - 6 } & Мышцы & Печень & Почки & Жабры & Скелет \\
\hline Бибинская И. & 214 & 139 & 142 & 249 & 244 \\
\hline Йокостровская И. & 177 & 108 & 111 & 184 & 198 \\
\hline Большая И._юг & 160 & 113 & 105 & 145 & 158 \\
\hline Большая И._север & 163 & 119 & 89 & 171 & 161 \\
\hline
\end{tabular}

\section{Заключение}

Установлено, что нагрузка стронция на экосистему оз. Имандра сохраняет тенденцию к росту. Накопление стронция обусловлено влиянием крупнейшего предприятия горно-добывающей отрасли. По-видимому, сиг, являющийся бентофагом, более уязвим и восприимчив к накоплению стронция в организме, что позволяет использовать его в качестве наиболее показательного тест-объекта, наряду с донными отложениями, при оценке нагрузки Sr на экосистему оз. Имандра. В современных условиях Бабинская Имандра, как наиболее удаленный от локальных источников загрязнения плес, в меньшей степени подвержена загрязнению рассматриваемым металлом. Показано, что применение индекса соотношения $\mathrm{Ca} / \mathrm{Sr}$ в тканях рыб, может быть использовано для анализа предпосылок развития заболеваний, схожих с уровской эндемией. Выявлена градиентная зависимость роста величины показателя $\mathrm{Ca} / \mathrm{Sr}$ у сига оз. Имандра по мере снижения интенсивности нагрузки стронция на акваторию водоема.

Работа выполнена в рамках тем НИР АААА-А19-119041890010-4 № 0226-2019-0045 и гранта РФФИ (№ 18- 05-60125).

\section{Литература}

1. Василенко И.Я., Василенко О.И. Стронций радиоактивный // Энергия: экономика, техника, экология. 2002. № 4. C. 26-32.

2. $\quad$ ГН 2.1.5.1315-03. Предельно допустимые концентрации (ПДК) химических веществ в воде водных объектов хозяйственно-питьевого и культурно-бытового водопользования. Гигиенические нормативы. М.: Минздрав России. 2003.

3. Замана Л.В., Гладкая Н.М. Геохимические особенности природных вод уровского биогеохимического района // Геохимия. 1993. №2. С. 269-280.

4. Ковальский В.В. Стронциево-кальциевые субрегионы биосферы и биогеохимические провинции // Тр. биогеохимической лаборатории АН СССР. 1978. Т. 15. С. 122-128.

5. Лаврищев А.В. Изучение поведения стабильного стронция в агроэкосистемах Северо-Запада России // Дис. соиск. уч.степ. докт. с-х. наук. С-Пб. 2016. 272 с.

6. Моисеенко Т.И., Даувальтер В.А., Ликин А.А., Кудрявцева Л.П., Ильяшук Б.П., Ильяшук Е.А., Сандимиров С.С., Каган Л.Я., Вандыш О.И., Шаров А.Н., Шарова Ю.Н., Королева И.М. Антропогенные модификации экосистемы озера Имандра. М. Изд-во: Наука. 2002. 403 с.

7. Мур Дж. В., Рамамурти С. Тяжелые металлы в природных водах. М. Изд-во: Мир. 1987. 287 с.

8. Петренко Д.В., Белюченко И.С. Содержание стронция в окружающих Белореченский химзавод ландшафтах // Экологически вестник Северного Кавказа. 2014. Т. 10. № 2. С. 63-75.

9. Полякова Е.В. Стронций в источниках водоснабжения Архангельской области и его влияние на организм человека // Экология человека. 2012. № 2. С. 9-14.

10. Moiseenko T., Dauvalter V., Rodyushkin I. Geochemical migration and covariation of elements in the Imandra Lake, Barents Region. Luleå: University of Technology, Sweden. Research Report TULEA. No. 22. 1996. 108 p. ISSN 0347-0881. 